University of Michigan Law School

University of Michigan Law School Scholarship Repository

\title{
Regulatory Purpose and 'Like Products' in Article III:4 of the GATT (with Additional Remarks on Article III:2)
}

Donald H. Regan

University of Michigan Law School, donregan@umich.edu

Available at: https://repository.law.umich.edu/book_chapters/57

Follow this and additional works at: https://repository.law.umich.edu/book_chapters

Part of the International Trade Law Commons, Organizations Law Commons, and the Transnational Law Commons

\section{Publication Information \& Recommended Citation}

Regan, Donald H. "Regulatory Purpose and 'Like Products' in Article III:4 of the GATT (with Additional Remarks on Article III:2)." In Trade and Human Health and Safety, edited by G. Bermann and P. Mavroidis, 190-223. Columbia Studies in WTO Law and Policy. New York: Cambridge Univ. Press, 2006.

This Book Chapter is brought to you for free and open access by the Faculty Scholarship at University of Michigan Law School Scholarship Repository. It has been accepted for inclusion in Book Chapters by an authorized administrator of University of Michigan Law School Scholarship Repository. For more information, please contact mlaw.repository@umich.edu. 


\section{Regulatory Purpose and "Like Products" in Article III:4 of the GATT (with Additional Remarks on Article III:2)}

\section{Prologue}

In EC - Asbestos the Appellate Body has told us that (1) in interpreting Article III:4 of the GATT, we must take explicit account of the policy in Article III: 1 that measures should not be applied "so as to afford protection to domestic production" [hereafter just "so as to afford protection"]. ${ }^{1}$ In Chile-Alcohol the Appellate Body has told us that (2) in deciding whether a measure is applied "so as to afford protection," we must consider "the purposes or objectives of a Member's legislature and government as a whole" - in other words, the regulatory purpose of the measure. ${ }^{2}$ Chile-Alcohol was decided under Article III:2, but it involves the very same "so as to afford protection" that Asbestos says we look to in interpreting Article III:4. It follows from (1) and (2) that in interpreting Article III:4, we must consider the regulatory purpose of the measure under review.

That is the doctrinal argument for the relevance of regulatory purpose under Article III:4. In the ten years since US - Malt Beverages, ${ }^{3}$ we have come full circle on this issue. ${ }^{4}$ Although I think the Appellate Body is now on the right track,

1 European Communities - Measures Affecting Asbestos and Asbestos-Containing Products, WT/DS135/ AB/R (12 March 2001) [hereafter Asbestos or EC-Asbestos], 1993, 98.

2 Chile - Taxes on Alcoholic Beverages, WT/DS87 \& DS1 10/AB/R (13 December 1999) [hereafter Chile Alcohol], $\lceil 62$.

3 United States - Measures Affecting Alcoholic and Malt Beverages, BISD 39S/206 (adopted 19 June 1992) [hereafter US - Malt Beverages].

4 Following the lead of US - Malt Beverages, the Panel in United States - Taxation of Automobiles, DS31 (11 October 1994), originated the famous "aims and effects" language, but the report was not adopted. Thereafter the Appellate Body rejected the "aims and effects" test, and purported to reject all consideration of legislative purpose, in Japan - Taxes on Alcoholic Beverages, WT/DS8 \& DS10 \& DS1 1/AB/R (4 October 1996) [hereafter Japan - Alcohol]. Japan - Alcohol was decided under Article III:2, but in European Communities - Regime for the Importation, Sale and Distribution of Bananas, WT/DS27/AB/R (9 September 1997) [hereafter Bananas III], $\uparrow 216$, the Appellate Body seemingly extended the ban on considering regulatory purpose to Article III:4, saying III:4 cases should be decided without explicit reference to the Article III:1 policy against protectionism. Chile-Alcohol commences the rehabilitation of regulatory purpose analysis, under Article III:2, second sentence, and Asbestos makes it clear that the consequences of Chile - Alcohol are much broader still. Obviously, there are complexities in the development that are beyond this footnote but that will be revealed as we proceed. This was just to explain roughly how we have "come full circle."

I am grateful to Rob Howse, Bob Hudec and Petros Mavroidis for comments on an earlier draft. Errors are of course my own. 
their double volte-face on the relevance of purpose illustrates the instability of doctrine - and the Appellate Body has not yet explicitly drawn the conclusion that their holdings in Asbestos and Chile - Alcohol entail. I shall therefore argue from the text of the agreement itself that we must consider regulatory purpose in applying Article III:4.

Indeed, I shall argue for a slightly narrower proposition - that the ordinary meaning of "like products" in the context of Article III:4 directs us to consider regulatory purpose in the course of deciding when products are "like." It may not be obvious that this is a narrower proposition, but it is; someone might argue that even though regulatory purpose must be considered under Article III:4, it is not properly considered as part of the "like products" inquiry. Rather, the "like products" inquiry should focus on "competitive relationship," which is one element of the general inquiry into "so as to afford protection," while regulatory purpose should be considered only in connection with a different aspect of Article III:4, the question whether foreign goods are accorded "less favorable treatment" than domestic goods. There is one puzzling paragraph in the Asbestos report that might suggest precisely this. ${ }^{6}$ To my mind, it is much more natural, and more in line with the ordinary meaning of the words of Article III:4, to consider regulatory purpose as an aspect of "like products." However, in arguing for that, I do not mean to exclude the possibility of considering regulatory purpose under the rubric of "less favorable treatment" as well.

\section{The Ordinary Meaning of "Like Products" in Article III:4}

I shall argue that the ordinary meaning of "like products" in the context of Article III:4 of the GATT requires us to consider the regulatory purpose of the measure under review. When the Panel in Malt Beverages considered regulatory purpose, this was not an assault on the integrity of the agreement. It was just what the agreement had always required. The argument that I now develop at length was sketched in an article on process-based measures written with Rob Howse. ${ }^{8}$ I want to give the argument a fuller treatment and discuss some more recent cases. I also want to emphasize that the argument is separable from our position on process-based measures, which I set aside completely in this chapter.

It is commonplace that "like products" may mean different things in different provisions of the WTO agreements. The Appellate Body has confirmed in EC-Asbestos that "like" means different things even in Article III:2, first sentence, and Article III:4. ${ }^{9}$

5 As it happens, I think the same is true of "like products" in Article III:2, first sentence, but since that is an even more controversial claim, I postpone it to section III.B below.

6 Asbestos, $\$ 100$, discussed in section III.A below.

7 For further discussion, see section III.A. One advantage, from my perspective, of considering regulatory purpose as part of "less favorable treatment" is that that would allow us to uphold process-based measures that embody a non-protectionist regulatory purpose, even if the products made with the different processes are physically identical and are held on that ground to be "like" (mistakenly in my view, see Robert Howse and Donald Regan, "The Product/Process Distinction - An Illusory Basis for Disciplining 'Unilateralism' in Trade Policy," European Journal of International Law (2000), Vol. 11 No. 2, pp. $249-289$.

8 Id.

9 Asbestos, $1 \uparrow 96,99$ 
Examining for the first time the meaning of "like products" in III: $4,{ }^{10}$ the Asbestos Appellate Body adopts the "ordinary meaning" approach, but to my mind they only carry it through halfway. They decide correctly that competitive relationship is a necessary condition for "likeness" of products, but having found this necessary condition, they seem to treat it as necessary and sufficient, thus leaving no room for consideration of, for example, regulatory purpose. ${ }^{11}$

Actually, the issue of whether competitive relationship is sufficient for likeness seems to be the precise issue between the concurring Member of the Division and his two colleagues. ${ }^{12}$ The concurring Member is willing to make a positive finding that asbestos fibers are not "like" PCG fibers, even without clear evidence on the matter of competitive relationship. In the context, this means he is treating competitive relationship as not sufficient for likeness. "It is difficult for me to imagine what evidence relating to economic competitive relationships as reflected in end-uses and consumers' tastes and habits could outweigh and set at naught the undisputed deadly nature of chrysotile asbestos fibers, compared with PCG fibers, when inhaled by humans, and thereby compel a characterization of 'likeness' of chrysotile asbestos and PCG fibers." ${ }^{13}$ Later, "[T]he necessity or appropriateness of adopting a "fundamentally' economic interpretation of the 'likeness' of products under Article III:4 of the GATT 1994 does not appear to me to be free from substantial doubt." ${ }^{14}$ There is some evidence in the report, which I shall discuss in section IIIA below, that even the two "majority" members may not be quite so firmly committed to an approach based solely on competitive relationship as the report sometimes suggests, and as the concurring member fears. We should also remember that the majority members did not need to consider anything more than competitive relationship to get the right result in Asbestos itself. They might approach a different case differently. For the moment, however, I shall continue to assume that the majority members do regard competitive relationship as necessary and sufficient for "likeness." I shall pursue the ordinary meaning analysis in my own way, and then return to comment on various aspects of the Asbestos report. ${ }^{15}$

So, what is the ordinary meaning of "like products" in the context of Article III: 4 ? It might seem that we need not worry about the context - that "like" has a sufficient, context-independent meaning, "physically similar." However, a moment's reflection reveals that this is inadequate. Any two objects are similar with regard to some physical properties and different with regard to others. So we need some independent criterion to tell us which properties are the ones that matter. (We also need some independent criterion to tell us what degree of similarity is required, with regard to the relevant properties, but that is a subsidiary issue.) The appeal to physical likeness

10 This is what the Asbestos Appellate Body says in $₫ 88$, deftly setting aside any possible relevance of ECBananas (of which more below) on the ground that in Bananas they were not called upon to address the meaning of "like products." $₫ 88$, n.57.

11 However, see the discussion in section III.A below of a relevant ambiguity in the Appellate Body's argument.

12 Uniquely in the annals of the Appellate Body, there is a "concurring statement" of six paragraphs by one Member of the Division interpolated into the report, Asbestos, ๆ『149-154.

13 Id. ๆ152.

14 Id. 9154.

15 See section III.A below. 
is seductive, for two reasons. First of all, even though we must look to something other than physical likeness for the basic specification of what matters, it remains true that whatever the ultimate ground of "likeness," as objects become more alike in their physical properties, they tend to become more alike in whatever way we are ultimately concerned with. ${ }^{16}$ Second, if two objects are perfectly physically identical, then they must be alike in any other respects that interest us. (Remember we have set aside the objects' history for purposes of this chapter.) However, no two objects in the real world are ever identical, and small differences may matter a great deal. The difference between a useless chemical compound and a wonder drug may be a single atom. So, physical likeness, even if it is in some sense necessarily correlated with what really matters, cannot provide the ultimate criterion. ${ }^{17}$

We have seen that in order to have a usable conception of "likeness," we need to know which properties matter. We need an answer to the question, "Like in what respects?" In the abstract, the answer is clear: products are like if they are alike in the respects that are relevant to our purpose in making the comparison. So now the question is, what is the purpose of making the comparison? To answer that question, we must turn to the context. Article III:4 tells us that:

The products of the territory of any contracting party imported into the territory of any other contracting party shall be accorded treatment no less favorable than that accorded to like products of national origin in respect of all laws, regulations and requirements affecting their internal sale, offering for sale, purchase, transportation, distribution or use.

This is not especially helpful. Plainly the general concern is with discrimination against foreign goods, but there are many possible understandings of discrimination, and Article III:4 gives us little help in deciding which is the relevant understanding.

Article III:1, however, which provides the context for all the further provisions of Article III, including III:4, is another matter. Article III:I tells us very clearly that the purpose of Article III is to prevent the application of measures "so as to afford protection to domestic production," which I shall abbreviate as "so as to afford protection." To be sure, the Appellate Body seems to have told us in Bananas III that we must not look to Article III:1 in interpreting III:4, because III:4 does not explicitly refer back to III: $1 .^{18}$ However, if the Bananas Appellate Body really meant to say that in interpreting III:4 we were not to consider in any way whether some measure was applied "so as to afford protection," then their prohibition cannot be honored. There is simply no way to give content to the phrase "like products" in Article III without referring to Article III: 1 and the basic purpose of avoiding protectionism. We have already

Even this claim must be taken with a grain of salt, since there is no unambiguous definition of "more alike in their physical properties." If we double one dimension of a square one unit on a side, have we made it more like a square two units on a side (because it is now like it in one dimension) or less like it (because we have turned the smaller square into a rectangle)?

17 For similar remarks, see Robert Hudec, "'Like Product': The Differences in Meaning in GATT Articles I and III," in Thomas Cottier and Petros Mavroidis, eds., Regulatory Barriers and the Principle of NonDiscrimination in World Trade Law (University of Michigan Press, 2000), p. 103. Incidentally, we shall see in section III.B below that we cannot make physical likeness provide the ultimate criterion even by interpreting it very narrowly, which was the stratagem adopted by the Panel and Appellate Body in Japan - Alcohol for dealing with Article III:2, first sentence.

Bananas III, ๆ216. 
established this with regard to Article III:4, and I shall explain in section III.B why it is true even under the narrower Article III:2, first sentence, which Bananas relies on as a controlling analogy. In any event, the Appellate Body in Asbestos, having earlier commented that Bananas did not involve the interpretation of "like products," 19 appeals explicitly to Article III: 1 and to the purpose of avoiding protectionism in interpreting III:4. ${ }^{20}$ So either Bananas actually does allow us to look to Article III: 1 in interpreting Article III:4 (I shall explain in section III.B how that might be the case), or else Asbestos implicitly revises Bananas.

We have decided that "likeness" must be interpreted in light of the purpose of avoiding protectionism. That is the only way to answer the question "like in what respects?" So, what features of products, what dimensions of likeness, does the purpose of avoiding protectionism make relevant? One set of features that we can see are relevant are features that matter to consumers. (Or more generally, to purchasers of the products, which may include manufacturers or processors using them as inputswe shall refer to all of these as "consumers" for convenience.) Only if two products are in competition can a measure that affects them unequally operate "so as to afford protection." And products can only be in competition if they are regarded by consumers as (to some degree) substitutes. So products cannot be "like" for purposes of Article III:4 unless they are viewed by the market as substitutes.

We now have a necessary condition for likeness. We have identified some relevant features - those that matter to consumers. However, have we identified all the features that matter to likeness? Have we found a sufficient condition? To see that we have not, consider the following simple example: Milk is sold in Barataria in cardboard cartons and in non-returnable plastic jugs. Some consumers prefer their milk in cartons, some in jugs, but all are left to make their own choice. Then the Barataria legislature discovers that the plastic jugs, because they are not biodegradable, damage the local environment in a way that cardboard cartons do not. Because Barataria has a long tradition of elevated concern for the environment, the legislature adopts a regulation forbidding the sale of milk in plastic jugs. As it happens, cardboard milk cartons are made in Barataria, while the non-returnable plastic jugs are made in neighboring Titipu, so the ban on plastic jugs benefits a local industry and hurts that industry's foreign competitor. Even so, it is clear that the impetus for the ban came from environmental quarters.

It might be, of course, that the ban is unnecessary, because once the facts about environmental damage are publicized, Barataria consumers will simply avoid plastic jugs on their own, but it might not work that way. There are at least two reasons why, in the absence of regulation, even fully informed Barataria consumers might continue to treat cardboard cartons and plastic jugs as close substitutes. (1) It could be that even though many Baratarians care deeply about the environment, the milk drinkers among them happen not to. In this case the environmental harm is a pure externality, and we need the ban to correct it. Alternatively, (2) it could be that even though milk drinkers care about the environment, it is still rational for each consumer who prefers plastic jugs to buy his milk in a jug, because the environmental cost from his 
own choice to purchase a plastic jug falls mostly on others. This would be a classic prisoners' dilemma. $^{21}$

If cardboard cartons and plastic jugs continue to be close substitutes in the market even after the environmental facts are known and publicized, and if we regard market substitutability as a sufficient condition for "likeness" of products under Article III:4, then the Barataria jug ban violates III: $4 .{ }^{22}$ However, that is not an acceptable conclusion. It should be clear that the ban is not "applied . . . so as to afford protection to domestic production" within the ordinary meaning of that phrase, and hence that the ban should not be held to violate Article III:4. The ban is simply not protectionist. To be sure, the ban burdens foreign producers disproportionately, but only because their product is disproportionately harmful to the environment. In other words, their product (plastic jugs) is not "like" the competing domestic product (cardboard cartons).

As I mentioned in the prologue, we could conceivably say that plastic jugs and cardboard cartons are "like" and then bring in regulatory purpose under the "less favorable treatment" rubric. However, if we understand that we must consider regulatory purpose somewhere, the "likeness" inquiry seems the most natural place. For a start, it should be obvious that if plastic jugs harm the environment and cardboard cartons do not, these products are not "like" in any ordinary sense. They differ in an important respect. Now we may wonder, what has regulatory purpose to do with this? The physical effects of cartons and jugs on the environment are independent of regulatory purpose - so why does the regulatory purpose matter at all? The answer, of course, is that even though the physical effects are independent of the regulatory purpose, the existence of a "harm" is not. If the effects on the environment are local, then whether the effects constitute a "harm" depends on the local evaluation of them, which is to say, on the evaluation by the Barataria regulator. So, whether plastic jugs "harm" the environment depends on the regulatory purpose; and therefore whether they are "like" cardboard cartons (which by hypothesis do no harm) depends on regulatory purpose as well.

If Barataria genuinely cares about the environment (specifically, if it genuinely disvalues the particular effects caused by jugs but not cartons), then jugs cause a harm, they are unlike cartons, and it is no Article III: 4 violation to treat them differently. On the other hand, if Barataria does not genuinely care about the environmental effects of the jugs, then jugs cause no actual harm, they are "like" cartons, and the ban violates Article III:4. This last result is just as it should be: if Barataria does not genuinely care about the environmental effects of the jugs, then the supposedly "green" jug ban is a protectionist ruse. Thus does regulatory purpose determine "likeness," and ultimately whether there is protectionism and an Article III:4 violation. ${ }^{23}$

21 There could also be a weaker sort of collective action problem: it might be that each consumer will eschew plastic jugs if, but only if, he knows enough others are doing so, in which case we may need legal intervention to provide information about the numbers.

22 I ignore for the moment the possibility of considering regulatory purpose under the rubric of "less favorable treatment," which I mentioned in the prologue and which I will address in the next paragraph.

23 For a very nice parallel discussion, see Frieder Roessler, The Legal Structure, Functions \& Limits of the World Trade Order (Cameron May, 2000), pp. 122-130. This is as good a point as any to comment on an issue that may be troubling some readers: if we consider regulatory purpose under Article III rather than postponing it to Article XX, who has the burden of proof? The answer is that the complainant has the 
Can it really be that the likeness of products under Article III:4 depends on the regulator's purpose? Even if someone's purpose must ground the answer to "like in what respects?," it was not the regulator who wrote Article III. True enough, but the conclusion stands. The purpose that matters most directly to the interpretation of "likeness" is of course the purpose of the drafters (and adopters) of Article III. Their purpose, as they have told us in Article III:1, was to prevent measures being applied "so as to afford protection." However, that purpose of the drafters is itself a complex one, and it is that purpose which directs our attention to the purposes of the regulatory body that adopted the measure under review.

If it still seems strange that "likeness" should ultimately depend on the purposes of someone other than the drafters of and parties to the treaty, notice that we have already encountered a much less controversial example of exactly the same phenomenon. We have already explained why products can be "like" only if they are substitutes in the market, and this requirement is by now widely recognized. Whether and to what extent they are substitutes depends precisely on consumers' purposes in buying the products. We can draw a veil over these purposes by talking about market forces and measured cross-elasticities of demand, but these forces and elasticities are merely the visible resultants of consumers' purposes. If consumers' purposes can be relevant to the likeness of products (because the ultimate purpose of the treaty provision makes them relevant), why not regulators' purposes as well (for the same reason)? It may help if we remember that regulators presumptively represent the purposes of the citizenry as a whole - people just like consumers, but a broader class. If consumers' purposes can matter to "likeness," why not the purposes of the citizenry at large?

So far my positive argument may seem to amount to little more than a bare assertion that the Barataria regulation is not protectionist. How can I be so confident that the phrase "so as to afford protection" encompasses only regulations with protectionist purpose - that it does not encompass innocently motivated regulations that have significant disparate impact on foreign products? First, there is the

burden of proof of showing protectionist purpose, since protectionist purpose is the crux of the basic violation. However, if that burden seems too heavy, we should remember the distinction between the burden of proof and the burden of going forward with the evidence. The "burden of proof" refers to the issue of who wins if, with all the evidence in, the probabilities seem equally balanced. The burden of proof of the basic Article III violation is and remains with the complainant. However, the complainant may well at some point produce enough evidence of protectionist purpose so that the defendant regulating country will lose unless they produce some evidence in response. (This is one possible meaning of a "prima facie case," although not the only one.) At this point, the defendant has the burden of going forward with the evidence - not in the sense that they have any legal duty to go forward, but in the practical sense that if they do not, they will lose. Often, I suggest, the complaining country will be able to shift the burden of going forward onto the defendant just by putting before the tribunal the text of the statute and a few basic facts about who produces what. In truth, in cases where the putative regulatory justification is one that is recognized by Article XX, it will often not make much difference whether we consider regulatory purpose under Article III or Article XX. (The burden of proof differs, but the burden of proof is usually not what decides the case. There may be other differences as well, for example in the precise way in which evidence about possible alternative measures is relevant, but such differences are not worth pursuing here.) The italicized qualification in the last sentence but two is important, because many perfectly sound regulatory policies are not recognized by Article XX. In any event, even when the differences in procedure and probable result are slight, we should apply the treaty as it is written. 
phrase itself - "so as to afford protection." To my ear, "so as to afford protection" has a strong purposive connotation. The reader should compare the phrase "measures applied so as to afford protection to domestic production" with a possible alternative such as "measures applied in such a way that they protect domestic production." By use of a dictionary and a grammar book one might conclude that these phrases are perfectly synonymous, but to my ear, they are very different in what they suggest about the relevance of purpose. The formulation with "so as to afford protection" has a much more purposive ring. ${ }^{24}$

This linguistic intuition may not seem conclusive by itself, but it is; strongly reinforced when we consider the context - not primarily the context of "so as to afford protection" in Article III:1, but the context of Article III in the GATT as whole. Why do we have Article III? We have it to prevent the use of internal restrictions to achieve goals that would otherwise be achieved by tariffs - both to preserve the value of negotiated tariff concessions, and, even where there are no concessions, as part of the project of channeling protectionism into the tariff mode so that it can be more easily negotiated down. Now, a tariff, the classic protectionist device, is both explicit in its discrimination against foreign products and purposeful. The object of the tariff is to put foreign products at a competitive disadvantage. ${ }^{25}$ So, if the point of Article III is to prevent countries from doing by indirection what tariffs do directly, then the paradigm case of an Article III:4 violation is a regulation that discriminates against foreign products explicitly and with protectionist purpose, like the indirect subsidy measure in the classic Italian Agricultural Machinery case. $^{26}$

In the years since Italian Agricultural Machinery, we have recognized that we cannot limit the prohibition of Article III to measures that discriminate explicitly against foreign products - that is, to origin-specific measures. Why not? Because if there were no discipline on origin-neutral measures, then carefully chosen origin-neutral measures could be used for the purpose of achieving protectionist goals. They could function as covert, or disguised, protectionism. So far so good. However, if the reason for disciplining origin-neutral measures is to prevent their use for the purpose of achieving protectionist goals, then the origin-neutral measures we want to suppress are those with protectionist purpose. That is the problem we are aiming at. The language of Article III and the function of Article III in the treaty as a whole both indicate that Article III is aimed at measures motivated by protectionist purpose. There is nothing about either the language or the treaty structure that points to any broader concern.

24 It is an interesting question what native speakers think about the formulations that correspond to "so as to afford protection" in the equally authentic French and Spanish texts of the treaty. The French formulation sounds purposive to my very non-native ear. The Spanish perhaps somewhat less so?

25 There may also be a revenue goal, but if there are import-competing producers of the same good, then the protectionist goal is manifested in the choice to raise revenue through a tariff rather than a neutral tax. If there are no import-competing producers, then the tariff might indeed be a pure revenue measure, but of course it could then equally be in the form of a neutral tax. The tariff might also be an "optimum tariff" designed to exercise collective monopsony power, but this situation is rare enough, at least in a pure form, so that the generalization in the text stands.

26 Italian Discrimination Against Imported Agricultural Machinery, BISD 7S/60 (adopted 23 October 1958). 
In response to my thesis that our concern is with protectionist purpose, it is often objected that although protectionist purpose is of course sufficient for a violation (at least in conjunction with competitive relationship), it cannot be necessary as I suggest. Two quite different claims are offered in support of this objection. The first claim is that if we require protectionist purpose for a violation, countries will be able to get away with too much covert protectionism; the dispute tribunals will be unable or unwilling to find protectionist purpose where it exists. Notice that this "objection" implicitly concedes that protectionist purpose is what we are worried about. The only dispute is about whether the inquiry into purpose should proceed directly or by indirection. What we would expect at this point is suggestions about presumptions or rules of thumb, which I am happy to incorporate into my approach, ${ }^{27}$ or perhaps observations about the significance of particular sorts of evidence, such as evidence about possible alternative measures. ${ }^{28}$ Instead, what we usually get is pronouncements that the issue of "so as to afford protection" must be decided "case-by-case," in the exercise of sound "judgment." This is true enough, but it provides no guidance at all in deciding any particular case. (As it happens, I think the tribunals' ability to deal with issues of purpose is already well demonstrated in practice, as I shall explain at some length in section III.B.)

The second major argument against making protectionist purpose necessary for a violation is an argument of principle that does not concede implicitly that purpose is the real crux. The argument is that even measures that have no protectionist purpose may impose costs on foreign interests that exceed the benefit to local interests. Such measures are inefficient in a standard (Kaldor-Hicks) sense. And the argument continues: if the GATT is concerned with efficiency, as it surely is at least in part, should it not forbid this sort of measure? The first point to make in response is that even if the GATT is concerned with efficiency, what Article III is concerned with is measures that are applied "so as to afford protection." I have been arguing that, in its ordinary meaning in context, that phrase refers to measures with protectionist purpose. It is perfectly plausible that the framers of the GATT (and later the WTO) meant to suppress one particular sort of inefficient measure, purposeful protectionism, which they thought the dispute mechanism could adequately identify, without aiming at another sort of inefficient measure whose identification requires a cost/benefit analysis. To my mind, the dispute tribunals are very poorly equipped to do cost/benefit analysis. It is ironic that some of the people who say dispute tribunals cannot identify purpose want to substitute an inquiry for which the tribunals are much less suited.

The second and more important point against the "Kaldor-Hicks interpretation" of Article III is that in the trade context we do not need judicial comparison of

One very important element here is the presumption, in effect, that origin-specific regulations are illegal. For an explanation of why the language of Article III compels distinct treatment of origin-neutral and origin-specific measures, even though it does not mention the distinction explicitly, see section II.A below.

28 Plainly, failure to use less-trade-restrictive measures that would achieve the asserted non-protectionist goal is strong evidence that the actual goal is protectionism. For fuller discussion, see Donald Regan, "Judicial Review of Member-State Regulation of Trade Within a Federal or Quasi-Federal System: Protectionism and Balancing, Da Capo," Michigan Law Review (August 2001), pp. 1853-1902, at 1870-1872, 1891-1892, 1899-1902. 
the foreign costs and local benefits to ensure that a non-protectionist regulation is Kaldor-Hicks efficient. Rather, we can be confident that a law like the Barataria jug ban is Kaldor-Hicks efficient, or at least that it should be presumed to be so by a dispute settlement tribunal. Why? The argument is in two stages. First, a tribunal applying Article III should presume that a ban imposed by the appropriate Baratarian institution is optimal from the point of view of Baratarian interests, provided it is motivated by concern for the environment and not by protectionism. That should be relatively uncontroversial. Second, in the trade context, a law which is optimal from the point of view of the local interests will be optimal globally. This second claim may seem counterintuitive. It obviously requires an argument, which I have given elsewhere but which is too long to develop fully here. ${ }^{29}$ All I can do here to make the claim more plausible is to suggest that the interests of foreign would-be traders are fully accounted for in the legislature's (non-protectionist, domestically optimizing) consideration of the domestic interests that want to trade with the foreigners.

By way of analogy, consider that in an unregulated failure-free market, consumers' choices in response to sellers' offers generate results that are efficient for both consumers and sellers. If a consumer decides that it is not in his interest to buy what some producer is offering, then the resulting non-purchase is efficient even though the consumer gives no thought at all to the seller's interests. For much the same reasons, if the government of Barataria correctly decides that it is not in the interests of Baratarians collectively that some good be consumed in Barataria, then the resulting non-purchases will be efficient (globally) even though the government of Barataria does not consider the foreign producers' interests. If the producers' product/ price offers do not attract the consumer's custom, we will not promote efficiency by compelling a purchase. This is as true when the "consumer" is a collectivity such as Barataria as it is when the consumer is an individual, provided the collective decision is not made on protectionist grounds. If Barataria's (non-protectionist) decision is presumed to be optimal for local interests, as it should be, then in this sort of context that amounts to a presumption of global optimality as well. In sum, there is no need for dispute tribunals to worry about whether non-protectionist trade regulation is Kaldor-Hicks inefficient. Article III is right, both on grounds of judicial competence and on grounds of theory, to make protectionist purpose the central issue. ${ }^{30}$

I have heard a rather different suggestion about why "so as to afford protection" should be interpreted to include a concern with regulatory purpose: such an interpretation is necessary to preserve the legitimacy of the WTO institutions. Member governments would not tolerate the application of a test based solely on disparate impact, nor even one that involved serious attempts by the tribunals at cost/benefit balancing. I think this is right, but we need the earlier analysis to explain fully why it is right. Governments would not be so jealous of a "right" to pass legislation that secured small local benefits at large foreign cost, if by giving up that right they could be protected against the losses they would incur when they were on the short end. Rather, governments understand that that is not what is at issue. They understand, vaguely no doubt, that when they decide on non-protectionist grounds that some product is inappropriate for local consumption, their decision creates no inefficiency 
even though it leaves some foreign producers worse off. The decision also imposes no "harm" or "injury" to the producers it leaves worse off, no more than would an individual consumer's decision to redirect his custom. Provided the ban is nonprotectionist, the foreign producers have no ground for justified complaint. So, if governments as regulators resist the idea that laws with disparate impact are ipso facto applied "so as to afford protection," they are not reneging on a commitment they made and now regret. They are merely insisting that the text of Article III be applied in accord with its ordinary meaning.

It is sometimes said that the GATT is a "commercial" or "economic" treaty, and therefore the criterion of "likeness" should be commercial or economic - hence we should consider competitive relationship, which is an economic phenomenon, but not regulatory purpose. However, it is grossly misleading to use the claim that the GATT is a "commercial" or "economic" treaty in this way. The GATT is undoubtedly a commercial or economic treaty in a loose sense, but it is not just about commerce or economics. Various Articles - Article III prominent among them involve major limitations on Members' regulatory powers. Because those regulatory powers encompass both economic and non-economic purposes, it is implausible that the parties would have intended the scope of interference with their regulatory powers to be determined solely by "economic" criteria limited to notions like competitive relationship. The commercial aspect of the treaty justifies the inclusion of competitive relationship among the criteria of likeness, but the other aspects of the treaty make it clear we should not exclude regulatory purpose. We have seen that even to identify the "economic" phenomenon of protectionism, we must be willing to consider whether there are non-protectionist (even non-economic) regulatory purposes that explain the disparate impact on domestic and foreign products. The project of suppressing protectionism, properly understood, leaves room for the full expression of divergent national values.

Let me close this section with a nutshell reminder of the main argument: (1) The meaning of "like products" depends on the purpose of Article III. (2) The purpose of Article III is to prevent protectionism. (3) The project of preventing protectionism requires us to consider the purposes of consumers (in the guise of "competitive relationship") and the purposes of regulators - because of what protectionism is. Not every alteration in competitive conditions is a protectionist "distortion." If a measure has a disproportionate impact on foreign products because foreign products are disproportionately harmful to some public value, then there is nothing to object to. As the Malt Beverages Panel said: “[T]he purpose of Article III is not to prevent contracting parties from differentiating between different product categories for policy purposes unrelated to the protection of domestic production." 31

31 US - Malt Beverages, ๆ5.25. I should mention somewhere the particular puzzle that is posed for purpose analysis by changed circumstances since the adoption of the law. Even if a regulation was adopted with an innocent purpose, it may be maintained for protectionist reasons. We could ask the question directly about the purpose of the non-repeal of the law - but often inaction has no such focused purpose as action. I have suggested elsewhere that we should deal with this problem by taking a hypothetical approach - asking whether it is reasonable to suppose that if the legislature enacted the regulation in the present, they might do so without protectionist purpose. For a fuller discussion, see Regan, supra note 28, pp. 1869-1870. 


\section{Objections and Answers: The Role of Article XX and the Ascertainability of Purpose}

\section{A. Article XX}

A standard argument against consideration of the regulatory aim under Article III (advanced by the Panel in Japan - Alcohol, but not repeated by the Appellate Body) ${ }^{32}$ is that such consideration would render Article XX inutile: If the measure under review is found to have a valid (non-protectionist) regulatory aim, it will not violate Article III, and there will be no need to consider whether it is excused by Article XX. If, on the other hand, the measure is found not to have a non-protectionist regulatory aim, then not only will it violate Article III, but there will be no candidate aim to consider as possibly grounding an exception under Article XX. Either way, Article XX plays no role, which violates the principle that we must not interpret a treaty in such a way as to render any provision inutile.

This argument is misguided for a number of reasons. First, even if it were true that considering the regulatory aim under Article III would leave no role for Article XX in Article III cases, it would not follow that Article XX was rendered inutile. It would still have a role to play in cases involving violations of any number of other provisions Article II, Article XI:1, Article X, and so on - where the language does not suggest a direct concern with regulatory aim at all. The principle of efficacy requires that a treaty provision have some function; it does not require that a treaty provision should have a substantive role to play in every case to which, because of its generality, it is formally applicable. ${ }^{33}$

In any event, it is not true that consideration of regulatory aim under Article III renders Article XX irrelevant to all Article III cases. In particular, origin-specific measures will be treated as de jure discriminatory. They will be held to violate Article III on their face and will be remitted automatically to Article XX. Now, to the reader who has just been following along with the flow of the argument, this first mention of de jure discrimination may come as a jolt. The distinction between de jure and de facto discrimination is normally thought to be a fundamental conceptual distinction, and yet we have not hitherto bumped up against it. In retrospect, it seems that all of our discussion of the meaning of "like products" has really been about when we should find de facto discrimination. However, we never made any conscious decision to focus the inquiry that way - it just happened as we pursued the meaning of "like products." What's going on? There is another reason to pause over the de jure/de facto distinction. I have just suggested that origin-specific measures, because they are de jure, are automatically held to violate Article III and remitted to Article XX. I

33 It has been suggested to me that perhaps an Article entitled "General Exceptions" should have some application to every prohibitory Article. This seems to read too much into a title. "General," in the context, means at most "broad, and formally universal," but not "universally efficacious in concreto." If a textual argument is required, it is worth comparing the title of Article XX, "General Exceptions," with the title of Article XXI, "Security Exceptions." If these titles are read as parallel in construction, then we see that "General" refers not to the range of other articles that may be excepted from (that is taken care of by the language "nothing in this Agreement" in both Articles XX and XXI), but rather to the nature of the considerations by which the exceptions are justified. 
think this is consistent with Panel and Appellate Body practice. And yet, the text of Article III does not distinguish explicitly between origin-specific and origin-neutral measures. Indeed, the Panel in Japan - Alcohol relied on that fact when it argued that the origin-specific/origin-neutral distinction could not justify different modes of analysis. ${ }^{34}$ Once again, what's going on?

The answer to both puzzles depends on the following observation: even though Article III does not distinguish explicitly between origin-specific and origin-neutral measures, the language and structure of Article III underwrite - I should say virtually compel - such a distinction. We have seen that in order to decide whether products that are treated differently by an origin-neutral measure are "like," we must first find some specific content for "likeness." We must decide what particular properties are relevant. It turns out that we can skip over that step when we are dealing with an origin-specific measure. The reason is that an origin-specific measure treats differently (or is potentially capable of treating differently) products that are identical in every respect except for their origin. However, products that are identical in every respect except for their origin must be "like" whatever the specific content of "likeness" in the context. If products that differed only in their origin could be "unlike," that would deprive Article III of all application; foreign products would never be "like" any local products, and it would be impossible ever to find that foreign products were treated less favorably than like local products. In sum, the language and purpose of Article III make it clear that all origin-specific measures must be held to distinguish between "like" products and thus to violate Article III (assuming the foreign products are given less favorable treatment). In contrast, we have seen that deciding whether origin-neutral measures violate Article III requires a substantive inquiry into the relevant meaning of "likeness." So, even though there is no explicit mention in Article III of a distinction between origin-specific and origin-neutral measures, the role of the "like products" concept in Article III compels such a distinction. ${ }^{35}$

It may seem that I still have not quite succeeded in giving Article $\mathrm{XX}$ a role in any Article III case. I have suggested that origin-specific measures violate Article III automatically and are therefore remitted to Article XX. How then could Article XX possibly save them? How could it ever be necessary, or even useful, to distinguish between products that are identical in every respect except for their origin? There are at least two possibilities here. The less interesting possibility for present purposes is that Article XX may in some cases justify "trade sanctions" - origin-specific measures that are adopted for the purpose of inducing the target country to change some policy of its own. I think many people are too quick to interpret genuinely regulatory measures by the importing country as trade sanctions in this sense, but trade sanctions do exist. They may even be attempts to induce a change in some policy of the target country that has no direct connection at all with the products on which the measure in question bears. Such a trade sanction might, in principle, be found to be justified under Article XX.

There is, however, a more interesting possibility, illustrated by Maine $v$. Taylor ${ }^{36}$ a United States Supreme Court case decided under the "dormant commerce clause."

\footnotetext{
Japan - Taxes on Alcoholic Beverages, WT/DS8 \& DS10 \& DS1 1/R, $₫ 6.16$.

Origin-specific measures may still be rescued by Article XX, of course.

477 U.S. 131 (1986).
} 
Maine $\nu$. Taylor as it stands would be an Article XI case under the GATT, so I shall tweak the facts a bit (and unfortunately make them more complicated) to make it an Article III case. Certain kinds of baitfish are used by the Maine fishing industry. These baitfish are produced both in state and out of state. Some (but not all) out-of-state baitfish are infested with a parasite that is unknown in Maine baitfish. In significant concentration, the parasite would be a danger to the Maine coastal ecosystem, but in low concentrations it is not. In order to minimize the risk that infested foreign baitfish will introduce the parasite in high concentration to any coastal area, Maine adopts a law that says foreign baitfish may not be sold or used in lots larger than some specified size. The law does not apply to domestic baitfish. This is an originspecific internal regulation affecting sale that treats foreign products less favorably than like domestic products. (Remember that not all foreign baitfish are infested with the parasite, so the Maine law does indeed disadvantage some foreign baitfish that are identical in every respect to local baitfish.) This is a violation of Article III:4, in effect just because of the origin-specificity. However, now we add a further fact: there is no non-destructive test for establishing which particular foreign fish are infested. It is therefore necessary, in order to protect Maine's ecosystem against dangerous concentrations of the parasite, to limit the sale of all foreign baitfish, including some non-infested "like" baitfish that, if the facts about each individual fish could be fully known, pose no danger at all. This ought to establish an Article XX(b) or XX(g) excuse for the Article III violation. The point, of course, is that this is a case (a relative rarity) where an origin-specific measure is necessary to achieve an "origin-neutral" (that is, non-protectionist) purpose. One function of Article XX is to rescue such cases. ${ }^{37}$

In parallel with its "inutility" argument, the Panel in Japan - Alcohol argued that if regulatory purpose were considered under Article III, then health measures, for example, would not be subjected to the stringent "necessity" standard prescribed by Article XX(b). ${ }^{38}$ This of course begs the question whether all health regulations are supposed to be subjected to that stringent standard. The structure of the GATT, under which measures are considered under Article XX only if they have already been

37 It might still be asked, "Why Article XX? Why not bring these considerations under Article III?" I argued above that all origin-specific measures violated Article III because they distinguished between products that were identical in all respects except their origin. We now see, from the baitfish case, that that is both true and not true. It is true in the sense that the Maine baitfish law will exclude some foreign non-infested baitfish that are in fact identical to local non-infested baitfish. It is not true in the sense that all the foreign baitfish, even the non-infested baitfish, are potentially infested - not known to be not infested and not knowably not infested - in a way that distinguish them from the local baitfish. We could say that this epistemological difference is enough to make all foreign baitfish "unlike" all local baitfish, so that the law does not violate Article III. There is a choice to be made here about the relevance of epistemological considerations to the interpretation of "likeness." My inclination, when we are confronted with an origin-specific measure, is to stick with the idea that the law excludes some identical foreign baitfish, even though we cannot identify the particular baitfish that is thus "improperly" excluded. It seems more in keeping with the general structure of Articles III and XX to say that origin specificity raises a strong presumption of illegality - both because it is rare that an origin-neutral purpose requires an origin-specific measure and because an origin-specific measure is particularly likely to be resented by the burdened foreign interests. We embody this strong presumption of illegality in our procedures by requiring that a justification for an origin-specific measure be proved under Article XX, where only certain justifications are available and the regulator bears the burden of proof. No such presumption of illegality can plausibly attach to origin-neutral measures with disparate impact. 
found to violate some other measure, gives no reason at all to think that the stringent standards of Article XX should be read back into Article III, directly or indirectly. Article III should be applied according to the meaning of its own terms. If anything, the Japan -Alcohol Panel's approach would be likely to cause a watering down of the Article XX standards. If measures are too easily held to violate Article III and passed along indiscriminately for review under Article XX, then dispute tribunals will feel compelled to interpret XX generously to uphold innocent-seeming measures. The result will be an Article XX that allows too many exceptions, at least if it is interpreted consistently, for measures that really do violate Article III properly interpreted, or Article XI, or whatever.

In sum, the danger from giving Article $\mathrm{XX}$ too much to do is at least as great as the danger from giving it too little. Article XX is not supposed to do the primary work of identifying violations. Its operation is supposed to be exceptional. It is entitled "General Exceptions." Plainly what is contemplated is a normally self-sufficient inquiry under Article III (or any other prohibitory Article), which is then revised by Article XX only in rare cases. As the Appellate Body says in Asbestos, "The scope and meaning of Article III:4 should not be broadened or restricted beyond what is required by the normal customary international law rules of treaty interpretation, simply because Article XX(b) exists and may be available to justify measures inconsistent with Article III:4."39

Finally, it might be suggested that considering only competitive relationship under Article III, and sending on to Article XX any case in which there is a disparate impact on foreign competing products, is at least a way to avoid the difficulties of reviewing regulatory purpose. I shall argue in the next section that the difficulties of purpose review are much overstated. Nor does relying on Article XX entirely avoid purpose review, which is required in some cases by the "disguised restriction" language in the chapeau of Article XX. In addition, the arguments of the previous two paragraphs, aimed against a different suggestion for slighting Article III in favor of Article XX, weigh heavily against this suggestion as well: the suggestion does violence to the ordinary meaning of Article III; it does violence to the status of Article XX as an "exceptions" clause; and it risks watering down the standards of Article XX, with the consequence that we make too many exceptions for genuine Article III violations.

\section{B. Identifying Regulatory Purpose}

Two standard objections to a test that considers regulatory purpose are (a) that purpose is too hard to identify and (b) that tribunals are or should be reluctant to find bad purpose because of the imputation of bad faith. The first step in answering both of these objections is to clarify what we mean by the "purpose" or "aim" of a legislature or a regulatory agency. Some people say that such corporate entities do not have purposes in the way individuals do. That is true - they do not have purposes in just the same way individuals do. Even so, we would find it impossible to talk or even think about their behavior without the metaphor of purpose. The question is, what lies behind the metaphor? 
I suggest that when we talk about the "purpose" of a legislature, we are not talking about any simple aggregation of the purposes of its individual members. We are talking, rather, about the political forces that produced the particular action or action whose "purpose" we wish to identify. When I introduced the example of the Barataria plastic jug ban, I said, concerning the regulatory purpose, that "the impetus for the ban came from environmental quarters." This is the first point that eases the task of identifying purpose: we do not need to peer inside the heads of individual legislators. We only need to ascertain what political forces are responsible for the measure under review. ${ }^{40}$

I am not suggesting, of course, that Panels should call in political scientists as "technical experts" and turn the purpose inquiry over to them. The question for a Panel or the Appellate Body in any particular case is always about the best understanding of what went on in that case. This is a question I think Panel members and, even more, Appellate Body members can handle better than most political scientists. The evidence will always be less than a scientist would want, and its nature and quality will vary from case to case. Panelists will vary in their competence to deal with the sort of question involved - many will be highly qualified but some may not but Appellate Body members are actually likely to be just the right sort of people to review determinations concerning purpose. They are people of wide "political" experience, whatever their precise career track. They are people who know how this aspect of the world works. That is not to say they will be infallible. Ascertaining the regulator's purpose is not always an easy task, but then, any sensible test will give rise to some hard cases. Tribunal members are actually better prepared to deal with the hard cases thrown up by a purpose test than with the hard cases under any other approach.

Nor should we forget that under the purpose test, many cases are easy. Many cases can be resolved by the merest commonsense appreciation of the content and context of the regulation. Consider the Asbestos case. The Appellate Body never allows itself to mention regulatory purpose, ${ }^{41}$ but isn't it obvious that if regulatory purpose were openly admitted to be part of the test, they could have written a much simpler and more persuasive report? They could have said that given the established facts about the dangers of asbestos, prohibiting asbestos (even with some minor temporary exceptions) is a completely natural thing for any legislature to do, and thus when confronted with a prohibition on asbestos, they (the Appellate Body) would assume it was adopted for non-protectionist reasons, even if it had a disparate impact on foreign products, unless they were given strong evidence to the contrary. (What sort of evidence to the contrary? Well, just for example, the sort of ministerial statements about the importance of protecting local businesses that the Appellate Body considered in Canada - Periodicals. ${ }^{42}$ Similarly in the Barataria jug hypothetical provided there is plausible evidence for the greater environmental costs of plastic jugs, the tribunal could say that banning plastic jugs was a fully understandable regulatory response to the problem, and once again, they would uphold the ban, even if

For a fuller discussion of how purpose is interpreted in terms of political process, and the advantages of such an approach, see Regan, supra note 28, pp. 1882-1889.

41

42

Capt briefly in stating an argument of the European Communities, Asbestos, $ๆ 86$.

Canada - Certain Measures Concerning Periodicats, WT/DS31/AB/R, \$VI.B.3. 
it had a disparate impact on foreign products, unless they were given specific reason to doubt its bona fides.

For an easy case in the other direction, consider the Mississippi wine tax invalidated in US - Malt Beverages, which gave a tax advantage to wine made with a particular grape that was grown only in the Southeastern United States and certain parts of the Mediterranean. ${ }^{43}$ Not only did this law prefer local wines, but, as the Panel pointed out, tax distinctions based on the type of grape were unknown in other state or federal laws. Indeed, it is hard to imagine a non-protectionist regulatory purpose. Or consider Chile - Alcohol, with its strangely broken graph of tax rate versus alcohol level. ${ }^{44}$ Or Japan -Alcohol, with its extremely disparate taxation of virtually identical products. ${ }^{45}$

As these cases illustrate, the tribunal can get a long way on "objective" evidence the text, structure, and foreseeable effects of the measure under review. It is crucial to understand that saying the ultimate question is purpose does not mean the tribunal can find a violation only if some responsible official has openly declared a protectionist purpose. Objective evidence, offered by the complaining country, will often be enough to shift to the defendant country the burden of going forward with the evidence, usually by asserting a non-protectionist regulatory justification. On the other hand, if there is relevant "subjective" evidence in the form of ministerial statements, or legislative committee reports, or whatever, the tribunal should consider that too, as the Appellate Body did in Canada - Periodicals, remembering always that even such "subjective" evidence is still just evidence. The tribunal need not invalidate a measure just because one legislator, or a few, who might not be at all representative, trumpeted an illegitimate purpose to curry favor with some constituency. And of course the tribunal does not have to uphold a measure just because an innocent purpose is asserted.

In two other very interesting cases, the Appellate Body engaged in purpose review under the "discrimination or disguised restriction" language in Article 5.5 of the Agreement on the Application of Sanitary and Phytosanitary Measures [SPS Agreement]. In EC - Hormones, the Appellate Body observed that "[n] o suggestion has been made that the import prohibition of treated meat was the result of lobbying by EC domestic producers of beef," 46 with the implication that such a suggestion would have been relevant to the proceedings. The Appellate Body also detailed sympathetically the understandable anxieties of European Communities consumers about the safety of meat. And it pointed to the felt need for some harmonized standard on hormones within the European Communities. ${ }^{47}$ In the end, it found no protectionist purpose. ${ }^{48}$ In Australia - Salmon, the Appellate Body was impressed by the change between the 1995 Draft Report (recommending that salmon imports be allowed) and the 1996 Final Report (recommending the ban on salmon imports), and they quote, in a context of general approval of the Panel's treatment of this point, the

43

44

45

46

47

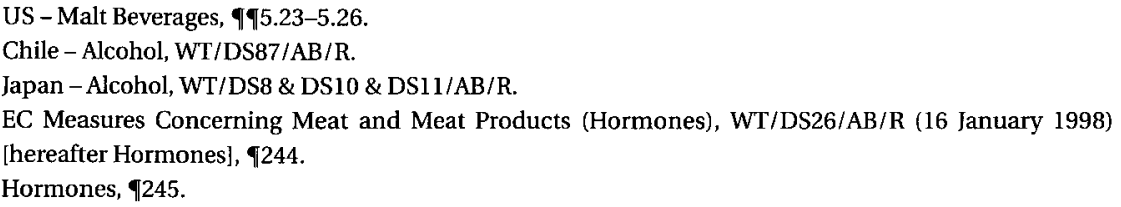


Panel's suggestion that the reversal might have been inspired by pressure from the local salmon industry seeking protection. ${ }^{49}$ The Appellate Body had said earlier that the measure's not being based on a risk assessment was "a strong indication" that the measure was a "disguised restriction." ${ }^{50}$ of course this had not been sufficient to establish protectionist purpose in Hormones. These two cases involved serious purpose inquiry, including the consideration of a range of evidence about the political process, and to my mind they came to very plausible conclusions. Of course, Hormones and Salmon were decided under the SPS Agreement; they are not directly relevant to the question whether Article III:4 requires consideration of regulatory purpose. However, they are highly relevant to the question of the Appellate Body's competence to determine purpose where the treaty requires it.

They are also relevant, Salmon especially, to the question of the Appellate Body's willingness to actually find protectionist purpose. It is often said that tribunals will be reluctant to explicitly impute bad faith, or that they should be, but why? Tribunals must stand ready to invalidate measures. Any ground of invalidation is going to involve some kind of criticism of the regulator - if not for bad purpose, then for wanton disregard of foreign interests (in choosing unnecessarily trade-restrictive measures, for example), or for scientific ignorance. It is not apparent why criticism for protectionist purpose is the one criticism that must be avoided. How serious is the "accusation" of protectionist purpose, which is leveled not at an individual but at a legislature or a regulatory agency? It is understood that a primary reason we need international agreements to suppress protectionism is that the forces of protectionism often wield excessive influence in domestic politics, which allows them to secure measures that are damaging even to domestic welfare. The tribunal that finds bad purpose is merely saying about a particular case, "Here is an instance where the local political process went awry in just the way the whole treaty mechanism presupposes it sometimes will. The domestic forces of economic good sense need our treaty-mandated support and intervention to correct the miscarriage." What is so terrible about that?

Even if we shift our focus from the local damage done by protectionism to the violation of reciprocity - the welching on an international bargain - it is still true that the basic reason for the misdeed is not that any person, natural or legal, is evil. It is just that politics is subject to distortions. And politics is subject to distortions everywhere. If the Panels and the Appellate Body decide to start naming protectionist purpose when they see it, they will not find themselves branding just one or two countries as uniquely miscreant. Almost every WTO member, and certainly every major player, indulges in purposeful protectionism from time to time. Is it not generally understood that the Appellate Body found protectionist purpose, whether or not they said so, in Japan - Alcohol, ${ }^{51}$ and Chile - Alcohol, ${ }^{52}$ and Canada - Periodicals, ${ }^{53}$ to name but a few? We should be willing to say what everyone knows, especially since doing so would allow a correct characterization of the real question in Article III cases.

51 See the discussion in section III.B below.

52 See the discussion later in this section.

53 See text accompanying note 42 supra. 
Let us conclude this section by looking at the Appellate Body's treatment of "so as to afford protection" in Chile-Alcohol, decided under Article III:2, second sentence. The Appellate Body quotes from Japan - Alcohol, "“[I]t is not necessary for a panel to sort through the many reasons legislators and regulators often have for what they do and weigh the relative significance of those reasons to establish legislative or regulatory intent." Continuing on their own, "The subjective intentions inhabiting the minds of individual legislators or regulators do not bear upon the inquiry, if only because they are not accessible to treaty interpreters." But then, "It does not follow, however, that the statutory purposes or objectives - that is, the purposes or objectives of a Member's legislature and government as a whole - to the extent that they are given objective expression in the statute itself, are not pertinent. To the contrary," and here follows the famous quote from Japan - Alcohol about looking at "the design, the architecture and the revealing structure" of a measure to discern "protective application." ${ }^{54}$ And later: "[A] measure's purposes, objectively manifested in the design, architecture, and structure of the measure, are intensely pertinent to the task of evaluating whether or not that measure is applied so as to afford protection to domestic production." 55

So, "the purposes or objectives of a Member's legislature and government as a whole" are pertinent, to the extent they are given objective expression in the statute. This is just what I have been referring to by "regulatory purpose." To be sure, the repeated references to the purpose being given "objective expression in the statute" might suggest that the only evidence we may consult regarding the legislature's purpose is the face of the statute itself. This is belied, not only by the Appellate Body's attention to ministerial statements in Canada - Periodicals, but by their further discussion of the right way to proceed in Chile - Alcohol itself. It transpires that the Panel must consider Chile's attempt to explain away the damning appearance of the measure considered in isolation.

In the course of agreeing with Chile that its measures need not be shown to be necessary to Chile's asserted purposes, the Appellate Body says:

It appears to us that the Panel did no more than try to relate the observable structural features of the measure with its declared purposes, a task that is unavoid able in appraising the application of the measure as protective or not of domestic production. ${ }^{56}$

Notice: consideration of "declared purposes" is "unavoidable." And in context it is clear that "declared purposes" means not purposes declared in the statute, but purposes declared to the Panel by Chile's lawyers. "In the present appeal, Chile's explanations concerning the structure of the New Chilean system... might have been helpful in understanding what prima facie appear to be anomalies in the progression of tax rates. The conclusion of protective application reached by the Panel becomes very difficult to resist, in the absence of countervailing explanations by Chile. The mere statement of the four objectives pursued by Chile does not constitute effective rebuttal on the part of Chile." 57

Chile - Alcohol, WT/DS87 \& DS110/AB/R (13 December 1999), 962 (emphases in original, including emphases added by the Chile Division to the Japan quote). 
What the Appellate Body is saying is this (the principal quotation marks that follow indicate an imagined, not an actual, statement - interior quotations are actual): "We are concerned with 'the purposes or objectives of [Chile's] legislature and government as a whole.' The first place we look to ascertain that purpose is the measure itself. This measure, with its peculiar structure so strikingly linked to facts about the precise alcohol levels of domestic and foreign spirits, is powerfully suggestive of protectionist purpose - enough so that if we looked only at the statute, we would hold that it was applied 'so as to afford protection.' Even so, Chile is entitled to a chance to explain away the initial appearance. Consideration of their 'declared purposes' is 'unavoidable.' But their explanations are unpersuasive, so we find that the measure has a protectionist purpose and violates Article III:2, second sentence."

So why is Chile entitled to try to persuade the Panel that the appearance on the face of the statute is misleading? Only because the ultimate question is not about what is on the face of the statute. The ultimate question is the legislature's actual purpose. Chile must show how the measure can be understood to "objectify" an innocent purpose. If they can show that it does objectify, that is, realize, an innocent purpose, they will prevail. Note also that if they produce a persuasive innocent interpretation of a measure that seems to bear an illegal purpose on its face, they will show at the same time that there is no unique purpose "revealed or objectified in the measure itself." Or more precisely, they will show there is no unique purpose objectified in the measure itself and identifiable by reference to the measure itself. If the measure can be shown to bear more than one reasonable interpretation, then the relevant purpose for the "so as to afford protection" inquiry must be the regulator's actual purpose (or our best evidence-based judgment about the actual purpose). The Appellate Body recognizes this just by saying Chile is entitled to contest the initial interpretation of the "objective" purpose of the measure. ${ }^{58}$

In sum, the Appellate Body is gradually acknowledging the role of regulatory purpose. I just want to hurry them along a bit. We have evidence already that they are up to the task of reviewing purpose and that when they openly find bad purpose, the heavens do not fall.

\section{EC - Asbestos and Japan - Alcohol}

\section{A. EC-Asbestos}

So far I have agreed with the Appellate Body in Asbestos on a number of points: (1) Article III must be taken seriously, not just skipped through on the way to Article XX; (2) Article III:4 must be interpreted in light of Article III:1; and (3) competitive relationship between products is a necessary condition for "likeness" under III:4.

It might seem that the Appellate Body in Korea - Taxes on Alcoholic Beverages, WT/DS75 \& DS84/AB/R (18 January 1999), denied the possibility of justifying a very unequal tax scheme when it said, "[T]he reasons given by Korea as to why the tax is structured in a particular way do not call into question the conclusion that the measures are applied 'so as to afford protection to domestic production." $\uparrow 150$. This could be read as saying that attempts at explanation are irrelevant in principle. However, in context the better reading is just that Korea's attempts at explanation were so thin as to be unpersuasive. [See the Panel report, WT/DS75 \& DS84/R (17 September 1998), ๆ $95.172-5.181$.] And if the Korea Appellate Body in fact meant that attempts at explanation are irrelevant in principle, then Chile - Alcohol, which is both later in time and more explicit, establishes the contrary. 
However, I have disagreed with their apparent finding that competitive relationship is not only a necessary condition for likeness, but also a sufficient condition. I have argued that the regulatory purpose of the measure under review must also be considered. The Appellate Body does not recognize the significance of regulatory purpose (at least not explicitly), but neither do they reject it explicitly. They simply do not mention it at all. ${ }^{59}$ However, we shall see that regulatory purpose lurks in the background of almost all they say, and that it must be brought in to make some of their arguments complete.

Presumably one reason the Appellate Body does not mention regulatory purpose is that regulatory purpose is not one of the indicia of likeness mentioned in the Border Tax Adjustment Report. ${ }^{60}$ The Appellate Body gives this report great prominence, with no explanation except that it has been relied on before. The Appellate Body starts its discussion of "likeness" (without at first mentioning the report) by inquiring into the ordinary meaning of the term in context. They get as far as deciding that "likeness" involves competitive relationship, with the suggestion that competitive relationship is a sufficient condition for likeness. ${ }^{61}$ They then digress into (a) the relation between Article III: 4 and Article III: $2^{62}$ and (b) the independent significance of the "no less favorable" requirement (both of which topics I shall discuss below). ${ }^{63}$ When they return to the interpretation of "likeness," it is as if they start all over, taking as their new jumping-off point the traditional list of considerations from the Border Tax Adjustment Report. ${ }^{64}$ After a few paragraphs of this, they reiterate that the real question is the competitive relationship between the products, whether or not we look to the report. ${ }^{65}$ Then they devote the bulk of the remaining analysis to the proper handling of the Border Tax criteria. As Robert Hudec has observed, the Border Tax list was never put forward as more than a representative list of possible criteria that had been suggested to or in the Working Party. ${ }^{66}$ Its canonical status should be reconsidered.

\section{The Border Tax Adjustment Criteria and "Competitive Relationship"}

For better or worse, the Appellate Body did rely on the Border Tax Report, so let us see how their argument goes. They begin with the first of the Border Tax criteria (as they summarize them), ${ }^{67}$ the physical properties of the product. They point out that asbestos and PCG fibers are chemically distinct, and that they are different in physical structure. Of course there is a question about why these physical differences matter. In a sense, the reason is utterly obvious: asbestos is a carcinogen that poses

Except, as I have noted previously, in summarizing an argument by the European Communities. EC Asbestos, WT/DS135/AB/R (12 March 2001), ๆ86.

"Thus, a determination of 'likeness' under Article III:4 is, fundamentally, a determination about the nature and extent of a competitive relationship between and among products." Asbestos, $\uparrow 99$.

62

63

64

65 Id., 999.

Id., $\ 100$.

Id., 9101.

Id., $\uparrow 103$.

Hudec, supra note 17, pp. 112-113.

Asbestos, $\uparrow 133$. 
a severe risk to human health, while PCG fibers, so far as we know, are not. This raises a further question, however, about just how the difference in health risk makes the products "unlike" for purposes of Article III:4. To my mind, there is once again an utterly obvious answer: the severe health risk explains why a regulator would ban asbestos, even without any protectionist purpose. However, the Border Tax list does not mention regulatory purpose, and this is not the answer the Appellate Body gives.

Instead, the Appellate Body moves on to another of the Border Tax criteria, consumers' tastes and habits. These are of course the underpinning of any "competitive relationship." The Appellate Body argues that the health risk makes it implausible that there is any competitive relationship between asbestos and PCG fibers. ${ }^{68}$ They argue in effect that with regard to the uses for which asbestos is banned, manufacturers would not buy asbestos in preference to PCG fibers even if they were allowed to, because of the health risk. There is something peculiar about this argument. If what the Appellate Body says is true, and known to the legislature, it does entail that the asbestos ban could not have been aimed at protecting domestic production of PCG fibers (which is how competitive relationship got into the discussion in the first place). It also raises the question of how the ban can serve any purpose at all. The Appellate Body's argument for why the ban is permissible seems to entail that it is pointless. Is that plausible?

Notice that there is a more standard sort of argument against the existence of a competitive relationship that raises no difficulty at all for understanding why the legislature acted. Consider a variant of our Barataria case: Barataria adopts its environmental ban on plastic milk jugs. The jug manufacturers challenge the ban on the ground that it does not apply to the domestically produced twenty-gallon metal containers that are used to deliver milk to institutional purchasers. Barataria responds by arguing, inter alia, that the twenty-gallon metal cans are not "like products" to the plastic jugs, because they are not substitutable. We can be persuaded of this claim without raising any question at all about why it is worth having a ban on plastic jugs. The argument against competitive relationship does not depend on arguing that there is no demand for plastic jugs (so long as the big cans are available) in the first place.

However, the Appellate Body's argument does involve arguing that there is no demand for asbestos (where PCG fibers can be used) in the first place. So it raises a question about why the ban is necessary. The mere fact that France had its asbestos ban suggests that their view about the shape of consumer preferences was more like Canada's view (that there was some market for banned asbestos, and some competitive relationship) than like the Appellate Body's view. It is still true, of course, that if the Appellate Body is right about the facts of consumer demand, then the law could not achieve any protectionist goal. However, this logically impeccable position seems to involve a sort of Alice-in-Wonderland view of the case.

Perhaps what the Appellate Body has in mind is the following: Fully informed and rational consumers would not buy asbestos. Therefore there would be no competitive 
relationship between asbestos and PCG fibers if consumers were fully informed and rational. Therefore a law that bans asbestos cannot be (or should not count as?) protecting PCG fibers. However, this is not what the Appellate Body says, and for good reason. "Rational" is a normative concept, and therefore how fully informed and rational consumers would behave is not an empirically observable economic fact (not even observable with difficulty, like cross-elasticities and actual competitive relationships given consumers as they are). Indeed, it seems all too clear that an appeal to the behavior of "rational" consumers would really be an appeal to the Appellate Body's own regulatory purpose, an appeal to their views about how consumers should behave. ${ }^{69}$ Better in principle to rely on France's regulatory purpose than to rely on the Appellate Body's - even when the purpose, protecting health, is the same. In order to avoid relying on either France's regulatory purpose or their own, the Appellate Body must argue that there is no actual competitive relationship, because consumers as they are will not buy asbestos. Which leaves us with the problem of why France passed the law.

There is a different peculiarity in the Appellate Body's discussion of manufacturerpurchasers of asbestos. ${ }^{70}$ The basic argument - that manufacturers will not buy asbestos because ultimate consumers will not buy products with asbestos - is doubly subject to the objection I have just raised: if consumers will not buy products with asbestos, and manufacturers therefore will not use asbestos, the need for any ban seems undercut at both levels. Aside from that, the Appellate Body also suggests that manufacturers may not buy asbestos because of possible civil liability. So why is it that domestic laws of delict that end up imposing greater liability on asbestos than on PCG fibers do not themselves violate Article III? They are certainly internal regulations that "affect" sale - that is precisely the Appellate Body's claim. Once again, it is completely obvious why such laws are GATT-legal - it is because asbestos is a powerful carcinogen. My point is just that this is not a claim about consumer preference; this is a regulatory justification. (Alternatively, one might say that the reason the liability laws are GATT-legal is that they are too general to be intended as protection for any particular product or set of products. True enough, but this argument again appeals to regulatory purpose.)

In sum, the Appellate Body's attempts to rely solely on competitive relationship, without bringing in regulatory purpose, either have an otherworldly air, or else require reference to regulatory purpose to complete them. Perhaps the Appellate Body thought WTO insiders were not yet ready for explicit appeal to regulatory purpose. However, I doubt that acknowledgment of the role of regulatory purpose can be put off much longer.

\section{The Roles of Physical Properties and Competitive Relationship}

The Appellate Body itself may have some ambivalence about the sufficiency of competitive relationship. If we return to the question of precisely how the physical differences between asbestos and PCG fibers, and the consequent difference in health

The Appellate Body acknowledges in a footnote that informed consumers sometimes make choices that involve risks to their health, as with tobacco. Id., ๆ122, n.103.

70 Id., $\$ 122$. 
risk, matter to the Article III analysis, we will find the report is ambiguous between the following subtly different positions:

(1) the physical differences and consequent different health risk make asbestos and PCG fibers physically unlike, and this unlikeness under one of the Border Tax categories counts in itself against a finding of overall likeness, so that even if the products were shown to be perfectly competitive, the weight of this consumer-habit-based "likeness" might not in the final analysis overbalance the independent weight of the physical-properties-based "unlikeness"; 71 or

(2) the physical unlikeness and consequent difference in health risk has no weight in itself, but it makes it presumptively implausible that consumers really regard the products as substitutes, so that in the absence of strong evidence of a competitive relationship, we will find no consumer-habit-based "likeness," and Canada has not carried its burden to show likeness by positive evidence. ${ }^{72}$

The distinction between (1) and (2) does not matter on the facts of Asbestos as the Appellate Body sees them, which is why it can go unresolved, perhaps even unnoticed. However, the choice would matter in the Barataria jug case, or indeed in any case where the physical difference and consequent cost to some public value matters to the public at large but does not influence the particular consumers of the harmful product (whether because they just don't care, or because of the sort of collective action problem we mentioned above). In such a case, assuming the consumer indifference can be shown, (2) will lead to a finding of "likeness," and thus to the invalidation of the measure. In contrast, (1) will allow the physical and public policy difference to be counted against "likeness" even when it has no effect on consumer behavior, so the products can be found "unlike" and the measure can be upheld.

As I say, the Asbestos report is ambiguous between (1) and (2). View (2) seems the more obvious reading, and it is the reading I implicitly assumed in previous sections when I said the Appellate Body treated competitiveness as a necessary and sufficient condition of likeness. However, if the correct reading is (1), then competitiveness is not sufficient, and regulatory purpose is back in the game, even if it does not appear on the scorecard. As we said many pages ago, if we try to locate likeness or unlikeness in physical characteristics, then the question arises about which physical characteristics matter. View (2) has an implicit answer to that - the physical characteristics that matter are those, and only those, that matter to consumers. If view (1) is the proper reading, then it is not consumer preferences, or not exclusively consumer preferences, that determine which physical characteristics are relevant. So what does determine which physical characteristics are relevant? The only possible answer is "regulatory purpose." Carcinogenicity is relevant because it reveals a plausible non-protectionist regulatory purpose for distinguishing between the products. That is how it makes the products "unlike." So, if view (1) is the proper reading, regulatory purpose is even nearer the surface of the Asbestos report than our previous discussion suggested. That is the hopeful view. 


\section{The Puzzle of $₫ 100$}

Another puzzle about the Appellate Body report in Asbestos concerns paragraph 100. The Appellate Body reminds us that even if two products are found to be like, there is still no violation of Article III:4 unless the imported products are given "less favorable treatment" than the domestic products. "[A] Member may draw distinctions between products which have been found to be 'like', without, for this reason alone, according to the group of 'like' imported products 'less favorable treatment' than that accorded to the group of 'like' domestic products."73 The Appellate Body explicitly declines to further examine the issue of "less favorable treatment," because there was no appeal from the Panel's findings on that issue. It is therefore not clear why they raised the matter at all. The Appellate Body says it wants to avoid misunderstandings that might be brought about in future cases by the "broad scope" they give to "like products," but they do not say what misunderstandings they anticipate.

It could be that the Appellate Body was suggesting another possible route to their result in Asbestos itself. They may have been suggesting that even if asbestos and PCG fibers were held to be "like," it would still be possible to say that the group of "like" imported products (Canadian asbestos-plus-PCG fibers) was not treated less favorably than the group of "like" domestic products (French asbestos-plus-PCG fibers), because foreign and domestic products were subjected to exactly the same regulatory regime. This argument gets the right result in the case before us, and what is more, it is obviously saying something true and relevant, but it cannot be taken at face value. If it suffices to avoid a violation that foreign and domestic products are subjected to the same regulatory regime, then an origin-neutral measure could never violate Article III:4. In other words, this argument would do away entirely with de facto discrimination.

So what is the real point that the argument is making? Here is a suggestion: Asbestos is treated less favorably than PCG fibers; and asbestos is the "foreign" product; but even so, asbestos is not treated less favorably because of its foreignness. The foreign product is not treated less favorably as such. In that sense, foreign products are not treated less favorably. (And why is asbestos treated less favorably, if not because it is foreign? Plainly, because it is dangerous.) We can make the same point from the other direction: Because an origin-neutral measure subjects domestic and foreign products to the same legal regime, it presumptively accords "no less favorable treatment" to foreign products; and the presumption is not rebutted just because the measure happens to have a disparate impact on foreign products. However, the measure does accord foreign products less favorable treatment, despite its facial neutrality, if it is adopted for the purpose of disadvantaging foreign products just because they are foreign. We might say the less favorable treatment is not in the measure itself, but in its adoption. Still, there plainly is less favorable treatment when imports as such are targeted for disadvantage. Whichever direction we make the argument from, we see that we are looking to regulatory purpose to give content to "less favorable treatment," just as we earlier looked to regulatory purpose to give content to "like products." There is more than one way we 
can bring regulatory purpose into the discussion, but one way or another it must be considered. $^{74}$

Remember we are trying to figure out why the Appellate Body reminds us in paragraph 100 that there is no violation without "less favorable treatment." We have considered one possibility, that they are suggesting an alternate route to the result in Asbestos itself. There is another possibility worth mentioning, though it has less to do with the actual facts of Asbestos. The Appellate Body might be reminding us that we should not find a violation under an origin-neutral measure unless there is disparate impact - that is, unless foreign goods lose, or can be expected to lose, market share to domestic goods as a result of the measure. (I am not suggesting disparate impact is sufficient for an Article III violation. I am suggesting it is necessary.) Suppose, contrary to fact, that both Canada and France produce both asbestos and PCG fibers, and that Canadian PCG fibers have the same fraction of PCG sales in France that Canadian asbestos has of asbestos sales in France. ${ }^{75}$ In these circumstances, if France passes a law disadvantaging asbestos vis-à-vis PCG fibers, that will affect sales of both asbestos and PCG fibers, but because Canada has the same share of both submarkets, there is no reason to think it will affect sales of Canadian asbestos-plus-PCG fibers any differently from the way it affects sales of French asbestos-plus-PCG fibers. There is no disparate impact; the group of foreign like products does not lose market share (nor is it disadvantaged with regard to "competitive opportunity"); there is nothing to suggest a protectionist purpose; and therefore there should be no violation.

The proposition that there is no violation in such a case seems almost too obvious to be worth asserting, but it is inconsistent with an argument advanced by the Malt Beverages Panel in striking down a New York tax that discriminated against beer from other states as well as from Canada. (They got the right result, but for the wrong reason.) The Panel suggested that there is a violation if foreign products are treated less favorably than the most favored "like" domestic product. ${ }^{76}$ In our example from the previous paragraph, there is a violation if Canadian asbestos (or even Canadian asbestos-plus-PCG fibers) is treated less favorably than "like" French PCG fibers (ignoring the treatment of French asbestos). I have explained elsewhere why this Malt Beverages argument does violence to the text of Article III, ${ }^{77}$ but our example reveals that it could also produce the unacceptable consequence of finding a violation of national treatment even without any disparate impact on foreign goods. ${ }^{78}$ It happens

74 It is not surprising that regulatory purpose should come in by two routes. There is one underlying question, about "so as to afford protection." If we divide that into a two-aspect question, about "less favorable treatment" of "like" foreign products, it is natural that the underlying issue can manifest itself through either aspect. The one minor difference is this: If we come to the question of regulatory purpose through the meaning of "like product," we are directed primarily to look for plausible non-protectionist purposes. In contrast, if we come to the question of regulatory purpose through the meaning of "less favorable treatment," we are directed more immediately to the question whether the actual purpose was protectionism. However, these are just opposite sides of the same coin.

75 I ignore the fact that France is part of the European Communities. This raises some genuine questions about which producers and which markets we should look at, but those questions are peripheral to the central point.

7 Howse \& Regan, supra note 7 , at $\mathbf{n} .22$.

78 In rejecting this argument from Malt Beverages, I cast no doubt on the result in United States - Section 337 of the Tariff Act of 1930, BISD 36S/345 (adopted 7 November 1989). The reason that product-by-product 
that if we analyze "like" along the lines I have been recommending, then this bad Malt Beverages argument could never actually lead to error. However, one thing the Appellate Body may be trying to do, on either interpretation of the point of paragraph 100 , is to construct a "fail-safe" procedure, so that errors at one stage of the analysis can be caught and cancelled at another ${ }^{79}$

\section{B. Japan-Alcohol}

In Japan - Alcohol, the Appellate Body dealt with Article III:2. Observing that Article III:2, second sentence, includes an explicit reference to Article III:1, while Article III:2, first sentence, does not, they concluded that the policy of Article III:1 (that measures not be applied "so as to afford protection") must inform the analysis under the two sentences of Article III:2 in different ways. Specifically, they said that Article III:2, first sentence, was intended as an independent and self-sufficient (partial) realization of the policy of III:1, so analysis under that sentence should proceed without explicit reference to III:1. In contrast, the analysis under III:2, second sentence, must include a step specifically adverting to the policy of III:1. ${ }^{80}$

I want to make four points about Japan - Alcohol, some that elaborate on things I have said elsewhere, some that are new. Here is a quick preview, to help the reader orient herself: (1) Contrary to what the Appellate Body says, Article III:2, first sentence, does not exclude direct consideration of "so as to afford protection." Indeed, at one point the Appellate Body clearly (but indirectly) acknowledge that they have considered "so as to afford protection" under III:2, first sentence. (2) Even so, the "so as to afford protection" policy of Article III: 1 informs the analysis differently under the two sentences of Article III:2, as the Appellate Body says it must. There is a difference in the way the two sentences work, but the Japan - Alcohol Appellate Body misdescribes it. (3) The Appellate Body's decision that III:2, second sentence, requires specific consideration of the "so as to afford protection" issue was correct, but it was not compelled by the text of Article III in the way they claim; rather, their decision reveals an implicit understanding that dissimilar treatment of competitive products is not a sufficient ground for finding an Article III violation. (4) Indeed, the

or case-by-case differences in treatment mattered in that case, even if, as the United States claimed, the overall statistics showed no disadvantage to the ensemble of foreign products subjected to patent challenge, was that the randomness itself, at the product or case level, imposed uncertainty costs on investors. There is no comparable uncertainty in my asbestos hypothetical.

This "fail-safe" idea was brought clearly into focus for me by conversation with Rob Howse. Notice that the existence of the "fail-safe" mechanism is not an argument for a more relaxed view about what are "like products" (and a fortiori not an argument for a more relaxed view about Article III, because Article $\mathrm{XX}$ waits in the wings). The point of a "fail-safe" mechanism is to have multiple safeguards against error (in this case, against inappropriate interference with innocent regulation).

There is a third possibility about Asbestos $\uparrow 100$, that it is just reminding us of the standard but important point that different treatment is not necessarily less favorable treatment. At least in principle, some treatment could be different but equally favorable. This is not very plausible as an interpretation of $\lceil 100$, since this point has not even a possible application to Asbestos itself. No matter how we slice up the universe of products in Asbestos, there is never a pair of products or product groups that we could plausibly think of as being treated differently but equally favorably. (Nor does this point seem more likely to be overlooked because "like products" is given a broad scope.)

80 Japan - Alcohol, WT/DS8 \& DS10 \& DS11/AB/R (4 October 1996), H.2. 
Appellate Body gives every appearance of understanding that the additional required element is protectionist purpose, even though they deny it.

Now back to the beginning. With regard to the first sentence of Article III:2, the Appellate Body says that because there is no explicit reference to Article III: 1 in that sentence, the issue of "so as to afford protection" is not to be considered directly. They say that the criteria of (i) taxes on imports "in excess of" those on (ii) "like" domestic products constitute a self-sufficient (partial) realization of the policy of III:1. Now we have the perennial question, when are goods "like"? In a rather murky discussion, the Appellate Body seems to focus primarily on physical properties. ${ }^{81}$ This could use some explanation, but I shall not object to this focus in the context. That still leaves the question, however, "Just how alike in their physical properties must products be in order to count as "like'?"

The Appellate Body says that "likeness" must be interpreted very narrowly in Article III:2, first sentence. ${ }^{82}$ The primary reason they suggest is that room must be left for III:2, second sentence, to have some scope. So far so good, but this tells us very little, because we do not know as yet either how broad the total scope of Article III:2 (both sentences) is to be, nor how it is to be divided between the sentences. At this point, the Appellate Body embarks on its long discussion of looking at all the evidence and exercising discretion, and it produces its famous "accordion" image. ${ }^{83}$

Surely it is clear that there is a second reason why "like" must be interpreted narrowly, which also helps us to see just how narrowly. If Article III:2, first sentence, is to be regarded as a self-sufficient (partial) realization of the policy of III:1, then "like" must be given a meaning that makes III:2, first sentence, work as a realization of that policy. "Like" must be given a meaning such that we are confident that any difference at all in the tax treatment of foreign and domestic products regarded as "like" does in fact reflect protectionism. So it turns out that we must consider the issue of protectionism after all, in order to assign meaning to "like," specifically in order to answer the question "how alike?" There is no alternative.

Notice I am not denying that we might in principle have a policy stated in one paragraph of a treaty or statute, and then a specific realization of that policy in another paragraph that can be applied without any reference at all to the first provision. Imagine a statute on public swimming pools that says in its first paragraph, "All public pools shall be safe for all swimmers using them," and then says in a later paragraph, "No pool for use by children under age five shall have a maximum depth greater than eighteen inches." Here the latter paragraph can be applied (at least to any ordinary case) without any attention at all to the underlying policy, but that is because "age five" and "eighteen inches" are precise terms with a clear independent content. "Like" is not similarly autonomous, not even after we have decided to concentrate on physical properties. The only way to give content to "like" in Article III:2, first sentence, is by reference to the policy of III:1. This can be done openly or covertly, but it must be done.

My claim is confirmed by a curious remark in the Appellate Body report in Japan - Alcohol. In the midst of their discussion of whether shochu and vodka are 
"like products," the Appellate Body suddenly says, in a strikingly obiter dictum, "We note that the determination of whether vodka is a 'like product' to shochu under Article III:2, first sentence, or a 'directly competitive or substitutable product' to shochu under Article III:2, second sentence, does not materially affect the outcome of this case." ${ }^{84}$ However, the Appellate Body tells us later that an invalidation under III:2, second sentence, would require an explicit finding that the dissimilar taxation was applied "so as to afford protection." 85 So their statement that it makes no difference whether we consider the vodka/shochu pair under the first sentence of III:2 or under the second sentence entails that the Appellate Body has decided the different taxation of vodka/shochu is applied "so as to afford protection." There is nothing remarkable in the content of this decision; what is important to notice is just that the Appellate Body had made it, consciously or unconsciously. They did not in fact reach a conclusion under III: 2 , first sentence, without adverting to the policy of III: 1 .

Post-Asbestos, the Appellate Body should simply acknowledge that interpreting Article III:2, first sentence, requires consideration of the policy of III: 1 . We can just run the Bananas reasoning backward. In its brief treatment of Article III:4, the Bananas Appellate Body told us that because III:2, first sentence, and III:4 were alike in not referring explicitly to III: 1 , the relation between III: 1 and those two other provisions must be the same. Bananas apparently followed Japan - Alcohol's treatment of III:2, first sentence, saying we should not look to III:1 in interpreting III:4. ${ }^{86}$ However, now the Asbestos Appellate Body has told us, correctly, that we must look to III: 1 in interpreting III:4. It follows by the Bananas major premise that we must look to III:1 in interpreting III:2, first sentence, also. So the Appellate Body can admit openly to what it is already doing. ${ }^{87}$

It might seem that the Dispute Settlement Body has rejected my proposal about how Article III:2, first sentence, works as recently as Argentina - Bovine Hides/Leather. ${ }^{88}$ Argentina argued that even though the "so as to afford protection" policy of Article III: 1 was not to be considered in a separate step under Article III:2, first sentence, it was nonetheless relevant in determining "likeness." ${ }^{89}$ The Panel, whose report was adopted without appeal, said in no uncertain terms that "so as to afford protection" was not to be attended to directly in any way, shape or form - neither as a separate step nor as part of the other required steps. ${ }^{90} \mathrm{I}$ have already explained why I think Panels and the Appellate Body cannot abide by this general prohibition, and I have pointed out that the Japan - Alcohol Appellate Body

84

85

EC - Bananas, WT/DS27/AB/R (9 September 1997), ๆ216. For an explanation of the "apparently," see note 91 below.

87

have fundamentally different structures, there is no inference from how III: 1 figures in the one to how it figures in the other. In fact, I would not argue that the Asbestos treatment of III: 1 and III:4 itself entails any conclusion about III:1 and III:2, first sentence. However, the Asbestos treatment of III:1 and III:4 certainly suggests and allows the view that we should look to III: 1 in interpreting III:2, first sentence, if there is independent reason to take that position, as we have seen there is.

88

90 Argentina - Measures Affecting the Export of Bovine Hides and the Import of Finished Leather, WT/DS155/R (adopted 16 February 2001).

Id., $\$ 11.133$.

Id., $\Upsilon 11.137$. 
indicated it did not abide by it. Ironically, the statement of the Argentina Panel makes perfect sense in its context. The reason is that Argentina involved an origin-specific measure. In a case like Japan - Alcohol, which involves an origin-neutral measure, the reason we must appeal to "so as to afford protection," even under III:2, first sentence, is to give specific content to "like" - that is, to answer the questions "like in what respects? and to what degree?" However, we saw in section II.A that we can decide that an origin-specific measure treats foreign products differently from "like" domestic products without assigning any specific content to "like." If we do not need to give a specific content to "like" in connection with an origin-specific measure, then we do not need to consider "so as to afford protection" in any way at all - just as the Argentina Panel says. It remains true that in dealing with an origin-neutral measure such as the measure involved in Japan-Alcohol, we must somehow attend to the "so as to afford protection" policy, even under Article III:2, first sentence. If there is no separate step, then the "so as to afford protection" policy must be part of the inquiry into "likeness."

It might seem that if we look to Article III: 1 when interpreting Article III:2, first sentence, then we do violence to the text in a different way, because nothing in our interpretive approach now reflects that fact that III:2, second sentence, refers back explicitly to III:1, while III:2, first sentence, does not. However, that is not true. There is still a difference in the interpretive approach to the two sentences. Under III:2, first sentence, on the approach I am suggesting, we look to the policy of III: 1 as part of deciding whether products are "like." That means that once we have made the decision on likeness, and then on taxation "in excess," there is no need to consider the policy of III: 1 in a separate step of the analysis. That policy has already been taken into account. In contrast, under III:2, second sentence, we can decide whether goods are "directly competitive or substitutable," and then whether they are "not similarly taxed" without considering the policy of III:1 (or at least we can come a lot closer to doing so). Hence, if the policy of III: 1 is to be considered, it must be brought in a separate step of the analysis, as the Japan - Alcohol Appellate Body required. The difference between the analyses under the two sentences of III:2 lies in whether considering the policy of III:I does or does not require a separate step.

This difference in the analysis under the two sentences of Article III:2 reflects a difference in the nature of the concepts "like" and "directly competitive or substitutable." The Appellate Body tells us that in III:2, "like" must be given a narrower meaning than "directly competitive or substitutable"; and there is no difficulty in arranging the requisite degree of likeness so that it in fact covers fewer cases. However, in a different way, "like" is essentially a broader notion than "directly competitive or substitutable." As we have pointed out, saying merely that we are concerned with the treatment of "like" products leaves completely open the dimensions of the comparison. It therefore allows us to select and focus on whatever dimensions are relevant to "so as to afford protection." (Specifically, it allows us to consider both competitive relationship and regulatory purpose.) Once we have made the decision about "likeness" in this light, the issue of "so as to afford protection" requires no further attention. In contrast, "directly competitive or substitutable" focuses on a specific dimension of comparison, the competitive relationship in the market. If this is not the only dimension relevant to "so as to afford protection" - as we have seen it is not - then we must give independent attention to the "so as to afford protection" 
issue, to bring in the other dimension. That is why III:2, second sentence, requires a "separate step," and III:2, first sentence, does not. ${ }^{91}$

There is evidence that the Appellate Body in Japan - Alcohol understood this difference between the nature of the concepts "like" and "directly competitive or substitutable," intuitively if not consciously. The Appellate Body claims that their three-stage structure of analysis under III:2, second sentence, is compelled by the text of the Article (with the Ad Note), but in truth it is not, or not in the way they say. Let us remember the language and structure. The primary text of Article III:2, second sentence, says:

Moreover, no contracting party shall otherwise apply internal taxes or other internal charges to imported or domestic products in a manner contrary to the principles set forth in paragraph 1 .

(Paragraph 1, of course, states the general principle that internal measures should not be applied "so as to afford protection.") The Note Ad Article III:2 reads:

A tax conforming to the requirements of the first sentence of paragraph 2 would be considered to be inconsistent with the provisions of the second sentence only in cases where competition was involved between, on the one hand, the taxed product and, on the other hand, a directly competitive or substitutable product which was not similarly taxed.

The Appellate Body asserts that this structure requires the dispute tribunals to address three separate issues under III:2, second sentence - (i) whether imported and domestic products are "directly competitive or substitutable," (ii) whether the products are "not similarly taxed," and (iii) whether the measure is applied "so as to afford protection." ${ }^{92}$ However, there is no strong textual reason why the Ad Note could not have been regarded as an independent and self-sufficient (partial) application of the policy of Article III:1 referred to in the primary text of III:2, second sentence, in exactly the same way that the Appellate Body said that III:2, first sentence, was an independent and self-sufficient (partial) application of Article III: 1 itself. In other words, there is no textual reason why the Appellate Body could not have said that a violation of III:2, second sentence, required only dissimilar taxation of directly competitive or substitutable products, and no more. It would be different if the three criteria listed above ("directly competitive or substitutable," "not similarly taxed," and "so as to afford protection") were all listed side by side in one sentence, but they are divided between two places. The third criterion, "so as to afford protection," appears, by reference to III:1, in III:2, second sentence, itself. The first two criteria appear in the Ad Note. It would be very natural to regard the Ad Note as not an addition to, but an explication of, the primary sentence. The Ad Note would then bear exactly the same relation to III:2, second sentence, that the Appellate Body says

91 If we look carefully, we will see that all the Appellate Body ever said about Article III:4 in Bananas was that the analysis did not require a separate step devoted to "so as to afford protection." I think saying that and only that, without explication of the role of "so as to afford protection" in the interpretation of "like products," was potentially very misleading and probably misled many readers. Still what they actually precisely said is completely consistent, both with what I am arguing here and with what they say about the relevance of III: 1 to III: 4 in Asbestos.

92 Japan - Alcohol, H.2. 
Article III:2, first sentence, bears to Article III:1. If anything, the passage the Appellate Body quotes from a drafting report at the Havana Conference suggests precisely this: "The details [of Article III] have been relegated to interpretative notes so that it would be easier for members to ascertain the precise scope of their obligations under the Article." ${ }^{93}$ This sounds more like the interpretative note is a self-sufficient spelling out of III:2, second sentence, than like it is an addition. ${ }^{94}$

My point is not that the Appellate Body got it wrong when they required separate consideration of "so as to afford protection" under Article III:2, second sentence. I think they got it right. My point is that they were making a choice, at least implicitly. And the best reason for making the choice they did, to require a separate step focusing on "so as to afford protection," is the point I made a moment ago: consideration of "directly competitive or substitutable" does not inevitably implicate consideration of (all relevant aspects of) "so as to afford protection" as consideration of "like" does. Furthermore, for reasons I expounded in section I , findings of "dissimilar treatment" of "competitive products" should not be regarded as sufficient grounds for finding a violation. The aspect of "so as to afford protection" that has not been considered in the course of making those findings, namely regulatory purpose, must be considered lest innocent, non-protectionist regulation or taxation be invalidated. All of this the Appellate Body may have grasped intuitively.

Did the Japan - Alcohol Appellate Body really grasp "all of this"? Did they grasp not only that we need a separate step under III:2, second sentence, to consider "so as to afford protection," but also that what is specifically required at that step is attention to regulatory purpose? I think the evidence is that they did. They considered regulatory purpose even as they claimed not to. Consider one of the most-quoted passages from the report:

Although it is true that the aim of a measure may not be easily ascertained, nevertheless its protective application can most often be discerned from the design, the architecture, and the revealing structure of a measure. The very magnitude of the dissimilar taxation in a particular case may be evidence of such a protective application, as the Panel rightly concluded in this case. ${ }^{95}$

Robert Hudec says about this passage, “The quotation makes a great deal more sense if one substitutes the word 'purpose' for 'application.' "96 I agree entirely. In addition, it is worth noting specifically the word "revealing" in the phrase "revealing structure." The clear implication is that attention to the structure will "reveal" something that is otherwise hidden. What could that be? It cannot be facial discrimination - that is too much on the surface to speak of it as being "revealed." It cannot be the actual effects of the measure - only empirical investigation of the measure in operation

Ibid., n.52, quoting from the drafting history at the Havana Conference, E/CONF.2/C.3/59, p. 8.

To be sure, treating the interpretative note as a self-sufficient spelling-out of III:2, second sentence, might not do justice to the precise logical import of the phrase "only in cases" in the Ad Note. "Only in" makes the conditions it names necessary, not sufficient. On the other hand, the use of "only in" does not deny that the named conditions are intended to be sufficient, if the general structure suggests that. I doubt the treaty drafters were always perfectly punctilious about necessary and sufficient conditions. Japan - Alcohol, H.2(c).

96 Robert Hudec, "GATT/WTO Constraints on National Regulation: Requiem for an 'Aims and Effects' Test," International Lawyer (Fall 1998), Vol. 32 No. 3; pp. 619-649, at 631. 
will reveal that. Surely what may be "revealed" by contemplation of the measure's design, architecture, and "revealing" structure is protectionist purpose. The use of the word "revealing" itself reveals the Appellate Body's thinking.

There is a further point about word usage. In the climactic paragraph of its report, the Appellate Body quotes and endorses the words of the Panel:

Thus, through a combination of high import duties and differentiated internal taxes, Japan manages to "isolate" domestically produced shochu from foreign competition, be it foreign produced shochu or any other of the mentioned white and brown spirits. ${ }^{97}$

"Manages"? In this context, the clear connotation of "manages" is disguised purpose. The Appellate Body found that the measure was applied "so as to afford protection" because they thought it was motivated by a purpose to protect domestic production.

\section{Summing Up}

Let us quickly review our main conclusions, in reverse order:

III.B. Despite its official doctrine, the Appellate Body in Japan - Alcohol did in fact think about "so as to afford protection" in connection with Article III:2, first sentence, and to all appearances they regarded protectionist purpose as the key to "so as to afford protection" in the discussion of III:2, second sentence.

III.A. The Appellate Body in EC-Asbestos relies on arguments about competitive relationship that make sense only if we supplement them with considerations of regulatory purpose. In addition, the Appellate Body's general discussion of the role of physical likeness and competitive relationship is more ambiguous and leaves more room for consideration of regulatory purpose than is apparent on a first reading.

II.B. In response to the claim that dispute tribunals are either incompetent or unwilling to find protectionist purpose, I pointed out that the Appellate Body already has a considerable track record of successful grappling with the issue of purpose - both in cases where they denied it or sidled around the issue (Japan - Alcohol, Korea - Alcohol, Canada - Periodicals) and in cases where they were quite open about their concern with purpose (Chile - Alcohol, EC Hormones, Australia-Salmon). The purpose inquiry does not require us to read the minds of individual legislators. It requires an appreciation of the political forces at work in the regulating body. (The regulation itself and its foreseeable effects remain of course the primary evidence.) This is an inquiry for which the dispute tribunals are much better suited than for any other well-defined inquiry that might be suggested for deciding this range of cases.

II.A. Considering regulatory purpose under Article III will not render Article $\mathrm{XX}$ inutile, nor even render it irrelevant to Article III. Origin-specific measures can be held to violate Article III on a per se basis and thus be remitted to Article XX. Although Article III does not distinguish explicitly between origin-specific and 
origin-neutral measures, we saw that such a distinction is entailed by the structure of the "like products" issue. The real danger in this area is not that we will give Article XX too little to do, but that by finding violations of Article III too easily, we will give Article XX too much to do and weaken it unduly as a result.

I. Consideration of regulatory purpose is required by the ordinary meaning of "like products" in the context of Article III:4. "Like products" must be interpreted in light of the "so as to afford protection" policy of Article III:1, and the existence of protectionism depends on regulatory purpose. Ordinary linguistic usage confirms this; the role of Article III in the GATT as a whole confirms this; and economic theory confirms this (regulation with a non-protectionist purpose should be presumed by WTO tribunals to optimize over local interests, and in the trade context, that is enough to guarantee global efficiency).

Prologue. The Appellate Body is already logically committed by its own doctrine to considering regulatory purpose under Article III:4. It remains only for them to draw the conclusion. 